\title{
Öğretmenlerin Bilişsel Esneklik ve Mesleki Doyum Düzeyinin İncelenmesi
}

\section{Investigation of the Level of Cognitive Flexibility and Job Satisfaction of Teachers}

\author{
Bahar ÜZÜMCÜ $\quad$ Ece Emre MÜEZZIN*
}

\begin{abstract}
Öz. Bu araştırmada Kuzey Kıbrıs Türk Cumhuriyeti'nde görevli öğretmenlerin bilişsel esneklik ve mesleki doyum düzeyi çeşitli değişkenler açısından incelenmiştir. Bu araştırma tarama modelinde nicel bir çalışmadır. Araştırmanın örneklemini 2014-2015 öğretim yılında Kuzey Kıbrıs Türk Cumhuriyeti (KKTC) Milli Eğitim Bakanlığı'na bağlı, devlet okullarında ve özel okullarda görevli 529 (402 kadın, 127 erkek) öğretmen oluşturmuştur. Bu çalışmada Bilişsel Esneklik Envanteri, Mesleki Doyum Ölçeği ve Kişisel Bilgi Formu kullanılmıştır. SPSS programı ile yapılan analizler sonucunda öğretmenlerin bilişsel esnekliğin kontrol alt boyutunda yaşa göre, bilişsel esnekliğin alternatifler alt boyutunda ve genel bilişsel esneklik düzeylerinde kıdeme göre ve bilişsel esnekliğin alternatifler alt boyutu düzeyinde görev yapılan kuruma göre anlamlı farklılık olduğu saptanmıştır. Öğretmenlerin mesleki doyum düzeylerinde cinsiyete, yaşa, görev yapılan kuruma, takdir alıp almama ve mesleğini severek yapıp yapmama durumlarına göre anlamlı farklılık olduğu belirlenmiştir. Öğretmenlerin bilişsel esneklik düzeyi ile mesleki doyum düzeyi arasında pozitif yönlü anlamlı bir ilişki ortaya çıkmıştır. Elde edilen bulgular doğrultusunda önerilerde bulunulmuştur.
\end{abstract}

Anahtar Kelimeler: Bilişsel esneklik, mesleki doyum, öğretmen.

\begin{abstract}
In this study cognitive flexibility and job satisfaction have been investigated in terms of various variables of teachers in Turkish Republic of Northern Cyprus (TRNC). This research is a quantitative study in survey model. The sample of study consisted of 529 (402 female, 127 male) teachers who worked in public and private schools depending on TRNC Ministry of National Education in the 2014-2015 academic years. In this research Cognitive Flexibility Inventory, Job Satisfaction Scale and Personal Information Form was used. As a result of the analysis with the SPSS program, the result of the study indicated that statistically significant differences were found in cognitive flexibility control subdimension of teachers according to their age, cognitive flexibility alternatives subdimension and general cognitive flexibility level of teachers according to their seniority and cognitive flexibility alternatives subdimension level of teachers according to institution. The results about job satisfaction indicate statistically significant difference in job satisfaction levels of teachers according to, gender, age, institution, appreciation, and the love of the profession. Furthermore, there are positive and significant correlations between cognitive flexibility and job satisfaction. In the direction of findings recommendations are given.
\end{abstract}

Keywords: Cognitive flexibility, job satisfaction, teacher.

\section{Toplumsal Mesaj.}

Bu çalışmada öğretmenlerin bilişsel esneklik ve mesleki doyum düzeyleri incelenmiş ve farklı değişkenler açısından değerlendirilmiştir. Çalışmada mesleki doyumla bilişsel esnekliğin ilişkili olduğu belirlenmiştir. Sonuç olarak bilişsel esnekliği yüksek olan öğretmenlerin mesleki doyumlarının da daha yüksek olduğu söylenebilir.

\section{Public Interest Statement.}

In this study, teachers' cognitive flexibility and job satisfaction levels are investigated and evaluated in terms of different variables. It is determined in the study that job satisfaction is correlated with cognitive flexibility. As a result, teachers with high cognitive flexibility can be said to have higher job satisfaction.

\footnotetext{
* Uzm., Uluslararası Kıbrıs Üniversitesi, Rauf Raif Denktaş Görme Engelliler Özel Eğitim Okulu, buzumcu@ciu.edu.tr

${ }^{* *}$ Yrd. Doç. Dr., Kıbrıs Sosyal Bilimleri Üniversitesi, Eğitim Fakültesi, Rehberlik ve Psikolojik Danışmanlık Bölümü, ece.muezzin@kisbu.edu.tr
} 


\section{GíRiş}

Her organizma, genler yoluyla gelen belli bir biyolojik ön yatkınlıkla yaşama başlar. Ayrıca her organizma, belli bir sosyo-kültürel grup, aile ve toplumsal çevre içinde yaşamını sürdürür (Aydın, 2000). Insanlar, içinde yaşadıkları çevreden devamlı, bilgi edinme çabasındadırlar. Ancak elde ettikleri bu bilgileri kendi kişilikleri, kültürleri ve deneyimleriyle harmanlayarak ve işleyerek anlamlı şekillere sokarlar sonra da bunları davranışlarının birer temel parçası olarak kullanırlar (Eren, 2010).

Bireyler büyüdükçe ve geliştikçe, gittikçe genişleyen bir çevreyle ve gittikçe artan uyaranlarla başa çıkmayı öğrenmeye başlarlar ve gerekli ayarlamaları yapabilirler (Çuhadaroğı, 2011). Birey davranışlarını gerçekleştirmeye karar vermeden önce, alternatiflerinin (seçeneklerinin) farkında olmalıdır. Belli bir konuyla ilgili alternatiflerinin farkında olan birey en doğru davranışı gören bireye kıyasla daha fazla düşünüyor demektir. Bu şekilde, birey konuyla ilgili çeşitlli çeşitli çözümler üretebilir. Önemli olan en doğru seçeneği bulmaktan ziyade, yapılacak davranışa karar vermeden önce alternatiflerin farkında olmaktır (Martin ve Anderson, 1998). Stahl ve Pry'a göre (2005) yeterli bilişsel esnekliğe sahip olanlar, yeni ve zor durumlarla etkili bir şekilde baş edebilir; alternatif düşünce ve fikirler üretebilirler (Akt. Gülüm ve Dağ, 2013). Bilişsel esneklik uygun bilginin seçilip kullanılmasını bunun için de durumu anlamayı ve karar vermeyi içerir (Spiro ve ark., 1988).

Spiro, Feltovich, Jacobson ve Coulson'a (1992) göre bilişsel esneklik kuramında "bilişsel" kısım, bilginin kazanılması anında eski öğrenilenleri bellekten çağrımasını, "esneklik" kısmı ise kazanılan bilgilerin çeşitli alanlarda esnek olarak kullanılmasını belirtmektedir. Ayrıca bilişsel esneklik, bireyin esnek olmaya istekli olmasını da içerir. Birey davranışta bulunmadan önce seçeneklerinin ayırdına varabilir. Fakat bu durum bireyin esnek olma isteği ile birleştiği zaman, seçenekler kullanılabilir hale gelecektir (Martin ve Anderson, 1998).

Bilişsel esneklik, algı, bellek ve hareketle ilgili süreçlerde programlama ve koordinasyon gerektirmektedir. Bilişsel esnekliğin planlama, organizasyon ve problem çözme becerilerine göre gelişimin erken dönemlerinde olgunlaşan bir beceri olduğu söylenmektedir (Güler, 2009). Öğrencilerin bilişsel esneklik becerilerinin gelişimi ve bilişsel esnekliği destekleyecek bilgi yapılarının edinilmesi, esnek öğrenme ortamlarında, aynı bilginin çeşitli yollardan ve çeşitli amaçlar için öğrenilmesini gerektirmektedir (Spiro ve ark.,1992). Bilişsel esneklik artık öğretmenlerin sahip olması gereken ve yetiştirecekleri öğrencilere de kazandırmaları gereken nitelikler arasında bulunmaktadır (Kılıç ve Demir, 2012).

Öğrenmede bilişsel süreçlerin açı̆̆a çıkarılması ve çevre ile etkileşimin belirlenmesi, öğretim yöntemlerinin yenilenmesine yol açmıştır. Öğrencilerin derslerde edilgen ve sadece dinleyici konumundan çıkarak, öğrenme sürecine etken bir şekilde dâhil olan, çevre ile etkileşime giren bilgileri zihninde yapılandıran bireyler olmalarının gerekliliği ortaya konmuştur. Öğretmenlerin de derste bilgiyi aktaran kişi olmaları yerine, öğrencilerin öğrenme süreçlerine dâhil olması için ortamı oluşturan ve öğrencileri yönlendiren bir konuma geçmesi önem taşımaktadır (Koçakoğlu, 2010).

Bireylerin eğitiminde ve topluma kazandırımasında çaba gösteren öğretmenlerin mesleki doyumlarının incelenmesi ayrı bir önem taşımaktadır (Kan, 2008). Mesleki doyumu yüksek olan öğretmenlerin, eğitime katkılarının ve performanslarının da yüksek olduğu söylenebilir (Karakuzu, 2013). Öğretmenlerin öğrencilerle kurdukları ilişkiler, meslektaşlarıyla ve okul yöneticileriyle olan ilişkileri, bireysel fikirlerini hayata geçirme olanakları, maaş ve tatil fırsatları, okul ortamı ve çalışma koşulları, ders saatleri, yükselme fırsatları, denetlenme ve takdir edilme gibi faktörler öğretmenlerin mesleklerinden duydukları doyumun kaynaklarıdır (Vural, 2004).

Shan'a (1998) göre öğretmenlerde mesleki doyum; yıpranmayı azaltmakta, meslektaş dayanışmasını artırmakta, iş performansını geliştirmekte ve öğrenci başarısını olumlu yönde etkilemektedir (Akt. Woods ve Weasmer, 2002). Öğretmenler için mesleki doyum yaptıkları işten duydukları memnuniyet ya da memnuniyetsizlik şeklinde veya öğretmenlerin öğrencilerine ve okullarına karşı tutumları şeklinde açıklanabilir (Vural, 2004). Öğretmenlerin mesleki doyumlarını 
anlamak için, öğretmenlerin iş tutumlarını ve iş davranışlarını anlamak gerekmektedir (Hongying, 2007).

Jackson, Schwab ve Schuler'a (1986) göre öğretmenlerin mesleki doyumunu belirleyen çeşitli faktörler vardır. Bu faktörler, alınan maaş, çalışma koşulları, çalışma saatleri, yöneticilerin tutumları ve davranışları ve çalışanın kişisel özelliklerini içermektedir. Öğretmenlerin mesleki doyumunu etkileyen en önemli içsel faktörler arasında, stres, çalışma koşulları, çalışma ortamı, okul ortamı; dışsal faktörler arasında ise, çalışanlarla ve yöneticilerle uyum içinde olma gibi faktörler sayılabilir (Akt. Şahin ve Dursun, 2009).

Öğretmenleri işlerinde güdüleme, onların verimini artırma ve bu yolla eğitim işlerinde doyuma ulaşmalarını sağlama işi ilk aşamada örgütün en önemli basamağı olan okulun başında bulunan okul müdürüne düşmektedir (Yıldız, 2013). Bu doğrultuda, öğretmenlere değişiklikler için söz sahibi olma yetkisi verilmesi, edilgen çalışanlar olmaktan çıkıp etkin kişiler olmalarının önünü açacaktır. Bir kez bireysel olarak aktif katılım sağlanması, otoritenin paylaşıması, anlamlı işler ile meşgul olunması, öğretmenlerin olumsuz duygulardan uzaklaşmalarına ve bilgilerini kanıtlayabilmelerine olanak sağlayacaktır (Woods ve Weasmer 2002).

Öğretmenlerin mesleki doyumları yükseldikçe profesyonellik ve yetkinlikleri de beraberinde yükselmekte, iş stresleri azalmaktadır (Pearson ve Moomar, 2005). Öğretmelerin yaşadığı mesleki doyum veya doyumsuzluk, görev yaptıkları okulun işleyiş ve düzenini etkilemektedir. Bu doğrultuda öğretmenlerin mesleki doyumlarını artırmak amacı ile yapılan her uygulama öğretmenlerin mesleki doyumları yanında, eğitimin iyileştirilmesine de katkı sağlayacaktır (Şahin, 2013).

Alanyazın incelendiğinde meslek hayatına devam eden öğretmenlerin bilişsel esneklik düzeyinin araştırıldığı sınırlı sayıda çalışmaya rastlanmıştır. Çuhadaroğlu (2011), öğretmen ve öğretmen adaylarıyla yaptığı çalışmasında, bilişsel esnekliğin yordayıcılarını araştırmıştır. Araştırma sonucunda şekilsel yaratıcılıkla bilişsel esneklik arasında olumlu yönde bir ilişki olduğu saptanmıştır. Katıımcıların bilişsel esneklik düzeyi, öğrenim gördükleri alana göre farklıık göstermezken, bilişsel esneklik ölçeğinde en yüksek puanın sözel bölümlerde öğrenim görenlere ait olduğu, ikinci sırada sanat bölümünde öğrenim görenlerin yer aldığı, en düşük puanın ise sayısal bölümlerde öğrenim görenlere ait olduğu ortaya çıkmıştır.

Sancar (2009), öğretmenlerin mesleki doyum düzeyini incelediği çalışmasında, ortaöğretimde görev yapan öğretmenlerin, müdürlerinin insan ilişkilerini ve iş odaklı tutumlarını, ilköğretimde görev yapan öğretmenlere nazaran daha yüksek algıladıklarını ve ortaöğretimde görev yapan yapan öğretmenlerin mesleki doyum düzeyinin daha yüksek olduğu belirlemiştir. Tümkan (2008), öğretmenlerin mesleki doyum düzeyini farklı değişkenlerle ele almış ve devlet okullarında görev yapan öğretmenlerin iş doyumu düzeyinin daha yüksek olduğunu ortaya koymuştur. Ayrıca öğretmenlerin iş doyumu düzeyinin cinsiyet, yaş, branş ve hizmet yılı değişkenleri açısından anlamlı farklılığa rastlamamıştır. Stempien ve Loeb (2002), genel eğitim ve özel eğitim alanlarında çalışan öğretmenlerle gerçekleştirdiği çalışmasında, genel eğitim alanında görev yapan öğretmenlerin mesleki doyum düzeyinin, özel eğitim ve her iki eğitim alanında da görev yapan öğretmenlerin mesleki doyum düzeyinden daha yüksek olduğunu ortaya koymuşlardır. Araştırma sonuçlarına bakıldığında, öğretmenlerin mesleki doyum düzeyini etkileyen çeşitli değişkenler olduğu görülmektedir.

Bir toplumda eğitimin en temel amacı o toplumun bireylerini topluma faydalı hale getirmektir (Küçükahmet, 1999). Bu amaca ulaşmada resmen sorumlu olan öğretmenlerin mesleki doyumlarının araştırıması önem taşımaktadır. Öğretmen, öğrenci ve yöneticilerle iyi ilişki kurma, kişisel ilgilerini gerçekleştirebilme, yükselme gibi ögelerin, öğretmenlerin mesleklerinden aldıkları doyumda olumlu etkisi olduğu vurgulanmaktadır.

Bilişsel esneklik düzeyi yüksek olan kişilerin, kişiler arası ilişkilerde kendini yeterli hissettiği, atılgan, sorumluluk sahibi, problem çözme becerilerinin gelişmiş, yeni durumlara uyum sağlamada esnek ve esnek olunan durumlarda kendilerini yetkin hissettikleri göz önüne alındığında, bilişsel esnek 
öğretmenlerin karşılaşabilecekleri zorluklar ve uyum süreçlerinin üstesinden başarıyla gelebilecekleri söylenebilir. Ayrıca günden güne artan teknolojik gelişmeler ve karşılaşılan problemlerin çeşitlenmesi, bilişim çağında dünyaya gelen öğrencilerin öğrenme süreçlerinde çağın etkilerinin görülmesi, öğretmenlerin kendilerini bu çağa ve nesile uydurma çabalarını beraberinde getirmektedir. Bu doğrultuda bilişsel esnek öğretmenlerin mesleklerinden daha fazla doyum sağlayabilecekleri düşünülmüştür.

\subsection{Amaç}

Bireyin gelişimini sağlarken, çevreden edindiği eğitsel olmayan tecrübeleri de eğitsel yöne dönüştürmeye çalışan öğretmenlerin bilişsel yeterlilikleri ve mesleklerinden aldıkları doyum, öğretimin verimliliğini etkileyebilecek faktörler arasında yer almaktadır. Literatüre bakıldığında "bilişsel esneklik" ve "mesleki doyum" konularının birlikte ele alındığı, Kuzey Kıbrıs Türk Cumhuriyeti'nde ise "bilişsel esneklik" konusunun ele alındığı bir çalışmaya rastlanmamış olmasından ve öğretmenlerin bilişsel esneklik ve mesleki doyum düzeyi arasında anlamlı bir ilişki olabileceğinden hareketle bu çalışma gerçekleştirilmiştir. Öğretmen yetiştirme programlarında bilişsel esneklik düzeyi yüksek öğretmenler hedeflenmesi ve öğretmenlerin mesleki doyum düzeyinin yükseltilmesine katkı sağlayacak düzenlemelerle, öğretim süreçlerinde verimi artırabilir olması bakımından bu çalışmanın etkili olabileceği düşünülmüştür. Ayrıca bu çalışmanın mesleki doyum ve bilişsel esneklik konuları üzerinde yapılacak çalışmalarda yol gösterir ve literatüre katkı sağlar bir çalışma olacağı düşünülmüştür. Bu doğrultuda, çalışmada öğretmenlerin bilişsel esneklik ve mesleki doyum düzeyini etkileyen faktörlerin ve öğretmenlerin bilişsel esneklik düzeyi ile mesleki doyum düzeyi arasındaki ilişkinin ortaya çıkarılması amaçlanmıştır. Bu doğrultuda aşağıdaki sorulara cevap aranmıştır:

1. Öğretmenlerin bilişsel esneklik düzeyleri;

a. cinsiyetlerine,

b. yaşlarına,

c. meslekteki kıdemlerine,

d. görev yaptıkları kuruma göre nasıl farklılık göstermektedir?

2. Öğretmenlerin mesleki doyum düzeyleri;

a. cinsiyetlerine

b. yaşlarına,

c. meslekteki kıdemlerine,

d. görev yaptıkları kuruma,

e. takdir alıp almama durumuna,

g. mesleğini severek yapıp yapmama durumuna göre nasıl farklılık göstermektedir?

3. Öğretmenlerin bilişsel esneklik düzeyleri ile mesleki doyum düzeyleri arasında nasıl bir ilişki vardır?

\section{YÖNTEM}

Öğretmenlerin bilişsel esneklik ve mesleki doyum düzeyinin bazı değişkenlere göre incelendiği bu araştırma tarama modelinde nicel bir çalışmadır. Tarama modeli ile bireyin kendi koşulları içinde, herhangi bir değiştirme ve etkileme yapmaksızın var olan durum olduğu gibi ortaya çıkarılmıştır. Var olan durumun sayısal veriler elde edilerek ortaya çıkarılması ile nicel bir çalışma gerçekleştirilmiştir.

\subsection{Evren-Örneklem}

Araştırmanın evrenini, KKTC Milli Eğitim Bakanlığı'na bağlı özel ve kamuya ait okul öncesi, ilkokul, ortaokul, lise ve özel eğitim okullarında görevli öğretmenler oluşturmaktadır. Araştırmanın 
örneklemini ise uygun örnekleme yöntemi ile belirlenen, 2014-2015 öğretim yılında KKTC'de Milli Eğitim Bakanlığı, İlköğretim Dairesi'ne, Ortaöğretim Dairesi'ne ve Mesleki Teknik Öğretim Dairesi'ne bağı 54 okuldan, \%76'sı (n=402) kadın \%24'ü $(n=127)$ erkek olmak üzere 529 öğretmen oluşturmuştur.

\subsection{Veri Toplama Aracı}

\subsubsection{Bilişsel Esneklik Envanteri (BEE)}

Bilişsel Esneklik Envanteri (BEE), Dennis ve Vander Wall tarafından geliştirilmiş, Volkan Gülüm ve İhsan Dağ tarafından 2012'de Türkçe'ye uyarlanmıştır. BEE, 'alternatifler' ve 'kontrol' alt boyutlarından oluşan toplam 20 maddelik öz bildirim türü bir değerlendirme aracıdır. Alternatifler alt ölçeğinin ilk ve son ölçümdeki Cronbach alfa değeri .91'dir. Kontrol alt ölçeğinin Cronbach alfa değerleri ise ilk ölçümde .86, son ölçümde .84'tür (Gülüm ve Dağ, 2012). Ölçek 5'li likert (1 Hiç uygun değil - 5 Tamamen uygun) tipinde yetişkinlere uygulanabilecek şekilde hazırlanmıştır. 20 maddeden oluşmaktadır. 2, 4, 7, 9, 11 ve 17. maddeler tersine puanlanan maddelerdir. 2, 4, 7, 9, 11, 15 ve 17. maddeler 'kontrol' alt boyutundadır. 1, 3, 5, 6, 8, 10, 12, 13, 14, 16, 18, 19 ve 20. maddeler 'alternatifler' alt boyutunda yer almaktadır. Her bir alt ölçeğe ait toplam puan hesaplanabileceği gibi genel bir 'bilişsel esneklik' puanı da hesaplanabilmektedir. Alt ölçek ya da ölçeğin genelinden alınan puanlar ile bilişsel esneklik düzeyi doğru orantılıdır. Ölçekten alınan puan arttıkça bilişsel esnekliğin de arttığı düşünülür (Gülüm, 2014)

\subsubsection{Mesleki Doyum ölçeği (MDÖ)}

Mesleki Doyum Ölçeği (MDÖ), çalışanların çalıştıkları işte kendilerini ne derece mutlu hissettiklerini belirlemek amacı ile Kuzgun, Sevim ve Hamamcı tarafından (1999) 'iki Faktör Kuramı' temel alınarak geliştirilmiştir. Faktör analizi tekniği kullanılarak ölçeğin yapı geçerliğini belirlenmiştir. Analizler 114 kişiden toplanan veriler üzerinde yapılmıştır. Faktör analizi sonucunda ölçeğin faktörlerinin iki kısma ayrıldığı tespit edilmiştir. Maddelerin özellikleri göz önüne alınarak faktör 1 "Niteliklere Uygunluk", faktör 2 ise "Gelişme İsteği" şeklinde isimlendirilmiştir. Ölçekte yer alan 1, 2, 4, 6, 7, 10, $13,16,17,22,23,26,27$ numaralı maddeler 1. Faktörü oluşturan maddelerdir. 11, 18, 20, 21, 24 , 25, 28 numaralı maddeler de 2. Faktörü oluşturan maddelerdir. İki faktörün toplam varyansı \%48.6 olarak açıklanmıştır. Bunun \%36.4'ü 1. faktörden, \%12.2'si de 2. faktörden kaynaklanmaktadır. Birinci faktör toplam varyansının \%36.4 olarak belirlenmesi ile ölçeğin tek boyutlu kullanılmasına karar verilmiştir (Kuzgun ve Bacanlı, 2005). Ölçeğin iç tutarlılık katsayısının hesaplanması ile güvenirliği belirlenmiştir. Ölçeğin tamamı için Cronbach Alpha katsayısı $=.90$ olarak belirlenmiştir. Birinci faktör için iç tutarlılık katsayısı .91, ikinci faktör için de .75 olarak tespit edilmiştir. Bununla bilrlikte toplam puan ile ölçeğin maddelerinden alınan puanların ilişkisi .30'dan yüksek olarak saptanmıştır (Kuzgun ve Bacanli, 2005).

Ölçek, 20 madde ile şimdiki şeklini almıştır. Bu maddeler beş basamaklı likert tipi (A: Her zaman, B: Sık sık, C: Ara sıra, D: Nadiren, E: Hiç) bir dereceleme ölçeği şeklinde ifade edilmiştir (Kuzgun, Sevim ve Hamamcl, 1999). 1, 2, 3, 5, 6, 7, 8, 12, 13, 15, 16, 17, 18, 20 numaralı maddeler "5: Her zaman, 4: Sık sık, 3: Ara sıra, 2: Nadiren, 1: Hiçbir zaman" şeklinde puanlanırken, 4, 9, 10, 11, 14, 19 numaralı maddeler olumsuz maddeleri oluşturmakta ve tersten "1: Her zaman, 2: Sık sık, 3: Ara sıra, 4: Nadiren, 5: Hiçbir zaman" şeklinde puanlanmalıdır. Bireyin mesleki doyumu alınan puanlarla belirlenir ve puanların yüksekliği mesleki doyumun yüksekliğini ortaya koyar (Kuzgun ve Bacanlı, 2005).

\subsubsection{Kişisel Bilgi Formu}

Araştırmada öğretmenlerin demografik özelliklerini belirlemek amacıyla kullanılan Kişisel Bilgi Formu araştırmacı tarafından geliştirilmiştir. Uzman görüşü alındıktan sonra düzenlemeler yapılmış ve uygulanabilir hale getirilmiştir. Kişisel Bilgi Formu öğretmenlerin; cinsiyeti, yaşı, medeni durumu, çocuk sahibi olup-olmama durumu ve varsa kaç çocuğa sahip olduğu, eğitim durumu, mezun olduğu program, meslekteki kıdemi, görev yaptığı kurum, kurumun türü, kurumda kaç yıl çalışıldığı, kurumdaki statüsü, kurumdaki öğrenci sayısı, öncesinde çalışılan kurumların sayısı, iş 
yaşamında mutlu hissedip hissetmediği, iş yaşamındaki başarılar için takdir alıp almadığı, aylık gelirini yeterli bulup bulmadığı, iş yaşamının özel hayatını etkileyip etkilemediği ve mesleğini severek yapıp yapmadığı ile ilgili 19 soru içermektedir.

Araştırma verilerinin toplanabilmesi için gerekli izinler, KKTC Milli Eğitim Bakanlığı'na bağlı, ilköğretim Dairesi'nden, Ortaöğretim Dairesi'nden ve Mesleki Teknik Öğretim Dairesi'nden alınmıştır. Çalışmanın yapıldığı tarihte, KKTC'yi oluşturan 5 ilçede (Lefkoşa, Girne, Mağusa, Güzelyurt, i̇skele) yer alan okullara, araştırmacı tarafından gidilerek, ülkenin tüm ilçeleri araştırmaya dahil edilmiştir. Araştırmaya katılmaya gönüllü olan öğretmenlere ölçeklerin araştırmacı tarafından birebir verilmesi ve ölçekler doldurulduktan sonra toplanması ile veriler elde edilmiştir.

\section{BULGULAR}

Bu bölümünde; ölçeklerden elde edilen veriler üzerinde yapılan, istatistiksel analiz çalışmalarına dayalı bulgulara yer verilmiştir. Bulguların sunulmasında, araştırmada cevap aranan alt problemlere uygun olarak öğretmenlerin bilişsel esneklik düzeyi ve mesleki doyum düzeyinin, bağımsız değişkenler yönünden incelenmesine ve öğretmenlerin bilişsel esneklik düzeyi ile mesleki doyum düzeyi arasındaki ilişkiye yer verilmiştir.

\subsection{Bilişsel Esneklikle ilgili Bulgular}

Öğretmenlerin bilişsel esneklik düzeyinin cinsiyete göre anlamlı farklılık gösterip göstermediği ilişkisiz örneklemler t-testi ile analiz edilmiştir. BEE kontrol alt boyutu düzeyinin cinsiyete göre anlamlı farklılık gösterip göstermediği incelendiğinde, 526 serbestlik derecesinde $t=-.925$ değeri ile $p=.356>.05$ sonucuna göre anlamlı farklılık bulunmamıştır. Alternatifler alt boyutu düzeyinin cinsiyete göre anlamlı farklılık gösterip göstermediği incelendiğinde, 527 serbestlik derecesinde $\mathrm{t}=$ .011 değeri ile $p=.992>.05$ sonucuna göre anlamlı farklılık bulunmamıştır. Genel bilişsel esneklik düzeyinin cinsiyete göre anlamlı farklılık gösterip göstermediği incelendiğinde, 526 serbestlik derecesinde $t=-.561$ değeri ile $p=.575>.05$ sonucuna göre anlamlı farklılık bulunmamıştır. Bu durumda cinsiyetin genel bilişsel esneklik düzeyi ve alt boyutları üzerinde anlamlı bir etkisi olmadığı söylenebilir.

Öğretmenlerin bilişsel esneklik düzeyinin yaşa göre anlamlı farklıık gösterip göstermediğini belirlemek amacı ile tek yönlü varyans analizi (One Way ANOVA) uygulanmıştır. BEE kontrol alt boyutu düzeyinin yaşa göre anlamlı farklılık gösterip göstermediği incelendiğinde, 22-30, 31-40, 4150 ve 51 ve üstü yaş gruplarındaki öğretmenlerin, 3/524 serbestlik derecesinde $F=3.597$ değeri ile $p=.014<.05$ sonucuna göre öğretmenlerin BEE kontrol alt boyutu düzeyinin yaşa göre anlamlı farklıık gösterdiği ortaya çıkmıştır. Yapılan Post Hoc testine göre 51 ve üstü yaş grubunda bulunan öğretmenlerin BEE kontrol alt boyutu düzeyi, diğer gruplardaki öğretmenlerden daha yüksek olarak belirlenmiştir. BEE alternatifler alt boyutu düzeyinin yaşa göre anlamlı farklılık gösterip göstermediği incelendiğinde, $3 / 525$ serbestlik derecesinde $F=.531$ değeri ile $p=.661>.05$ sonucuna göre anlamlı farklılık bulunmamıştır. Genel bilişsel esneklik düzeyinin yaşa göre anlamlı farklılık gösterip göstermediği incelendiğinde, $3 / 524$ serbestlik derecesinde $F=1.421$ değeri ile $p=.236>.05$ sonucuna göre anlamlı farklılık bulunmamıştır.

Öğretmenlerin bilişsel esneklik düzeyinin kıdeme göre anlamlı farklılık gösterip göstermediğini belirlemek amacı ile tek yönlü varyans analizi (One Way ANOVA) uygulanmıştır. BEE kontrol alt boyutu düzeyinin kıdeme göre anlamlı farklılık gösterip göstermediği incelendiğinde, 5 yıl ve altı, 6$15 \mathrm{yıl}, 16-25 \mathrm{yıl}$ ve $26 \mathrm{yıl}$ ve üstü kıdem gruplarındaki öğretmenlerin, 3/524 serbestlik derecesinde $F=2.236$ değeri ile $p=.083>.05$ sonucuna göre anlamlı farklılık bulunmamıştır. BEE alternatifler alt boyutu düzeyinin kıdeme göre anlamlı farklılık gösterip göstermediği incelendiğinde, 3/525 serbestlik derecesinde $F=3.775$ değeri ile $p=.011<.05$ sonucuna göre öğretmenlerin $B E E$ alternatifler alt boyutu düzeyinin kıdeme göre anlamlı farklıık gösterdiği ortaya çıkmıştır. Yapılan Post Hoc testine göre farklılığın 16-25 yıl kıdeme sahip öğretmenlerle, 5 yıl ve altı ve 6-15 yıl kıdeme 
sahip öğretmenler arasında olduğu görülmüş ve 16-25 yıl kıdeme sahip öğretmenlerin BEE alternatifler alt boyutu düzeyi daha yüksek olarak belirlenmiştir. Genel bilişsel esneklik düzeyinin kıdeme göre anlamlı farklılık gösterip göstermediği incelendiğinde, 3/524 serbestlik derecesinde F= 3.205 değeri ile $p=.023<.05$ sonucuna göre öğretmenlerin genel bilişsel esneklik düzeyinin kıdeme göre anlamlı farklılık gösterdiği ortaya çıkmıştır. Post Hoc testi ile bu farklılığın 16-25 yıl kıdeme sahip öğretmenlerle 5 yıl ve altı kıdeme sahip öğretmenler arasında olduğu görülmüştür. 16-25 yıl kıdeme sahip öğretmenlerin genel bilişsel esneklik düzeyinin 5yıl ve altı kıdeme sahip öğretmenlerden daha yüksek olduğu belirlenmiştir (Tablo 1).

Tablo 1. Öğretmenlerin BEE Alternatifler alt boyutu ve genel bilişsel esneklik puanlarının kıdem değişkenine göre Post Hoc testi sonuçları

\begin{tabular}{|c|c|c|c|c|}
\hline & (I) & (J) & $\begin{array}{c}\text { Ortalamalar Arası Fark } \\
(\mathrm{I}-\mathrm{J})\end{array}$ & $\mathrm{p}$ \\
\hline \multirow{6}{*}{ BEE Alternatifler } & \multirow{3}{*}{5 yıl ve altı } & 6-15 yıl & -.67640 & 1.00 \\
\hline & & 16-25 yıl & -2.22340 & $.015^{*}$ \\
\hline & & 26 yıl ve üstü & -.95870 & 1.00 \\
\hline & \multirow{2}{*}{ 6-15 yıl } & $16-25 \mathrm{yll}$ & -1.54701 & $.045^{*}$ \\
\hline & & 26 yıl ve üstü & -.28230 & 1.00 \\
\hline & 16-25 yıl & 26 yıl ve üstü & 1.26471 & 1.00 \\
\hline \multirow{6}{*}{ BEE Genel } & \multirow{3}{*}{5 yıl ve altı } & 6-15 yıl & -1.27987 & 1.00 \\
\hline & & $16-25$ yıl & -3.08249 & $.034^{*}$ \\
\hline & & 26 yıl ve üstü & -3.30476 & .331 \\
\hline & \multirow{2}{*}{ 6-15 yıl } & $16-25 \mathrm{yıl}$ & -1.80263 & .233 \\
\hline & & 26 yıl ve üstü & -2.02489 & 1.00 \\
\hline & $16-25 \mathrm{yll}$ & 26 yıl ve üstü & -.22226 & 1.00 \\
\hline
\end{tabular}

$* \overline{p<.05}$

Öğretmenlerin bilişsel esneklik düzeyinin görev yapılan kuruma göre anlamlı farklılık gösterip göstermediğini belirlemek amacı ile tek yönlü varyans analizi (One Way ANOVA) uygulanmıştır. BEE kontrol alt boyutu düzeyinin görev yapılan kuruma göre anlamlı farklılık gösterip göstermediği incelendiğinde, okul öncesi, ilkokul, ortaokul, lise, ortaokul ve lise ve özel eğitim okulu gruplarındaki öğretmenlerin, 5/522 serbestlik derecesinde $F=1.496$ değeri ile $p=.189>.05$ sonucuna göre anlamlı farklılık bulunmamıştır. BEE alternatifler alt boyutu düzeyinin görev yapılan kuruma göre anlamlı farklılık gösterip göstermediği incelendiğinde, 5/523 serbestlik derecesinde $F=2.645$ değeri ile $p=.022<.05$ sonucuna göre öğretmenlerin BEE alternatifler alt boyutu düzeyinin görev yapılan kuruma göre anlamlı farklııı gösterdiği ortaya çıkmıştır. Yapılan Post Hoc testine göre farklıı̆ın okul öncesi kurumlarda çalışan öğretmenlerle, özel eğitim okullarında çalışan öğretmenler arasında olduğu görülmüş ve okul öncesi kurumlarda çalışan öğretmenlerin BEE alternatifler alt boyutu düzeyi daha yüksek olarak belirlenmiştir (Tablo 2). Genel bilişsel esneklik düzeyinin görev yapılan kuruma göre anlamlı farklılık gösterip göstermediği incelendiğinde, 5/522 serbestlik derecesinde $F=2.264$ değeri ile $p=.047<.05$ sonucuna göre öğretmenlerin genel bilişsel esneklik düzeyinin kıdeme göre anlamlı farkıılık gösterdiği ortaya çıkmıştır. Fakat yapılan Post Hoc testinde anlamlı bir farklıı̆̆a rastlanmamıştır. 
Tablo 2. Öğretmenlerin BEE Alternatifler alt boyutu puanlarının görev yapılan kurum değişkenine göre Post Hoc testi sonuçları

\begin{tabular}{|c|c|c|c|c|}
\hline & (I) & $(\mathrm{J})$ & $\begin{array}{c}\text { Ortalamalar Arası } \\
\text { Fark (I-J) }\end{array}$ & $p$ \\
\hline \multirow{15}{*}{$\begin{array}{l}\text { BEE } \\
\text { Alternatifler }\end{array}$} & \multirow{5}{*}{ Okul Öncesi } & İlkokul & 2.17129 & .067 \\
\hline & & Ortaokul & 1.56775 & 1.00 \\
\hline & & Lise & 1.55095 & .811 \\
\hline & & ÖzelEğitim Okulu & 4.45956 & $.033 *$ \\
\hline & & Ortaokul ve Lise & 1.93248 & .571 \\
\hline & \multirow{4}{*}{ Illkokul } & Ortaokul & -.60354 & 1.00 \\
\hline & & Lise & -.62033 & 1.00 \\
\hline & & Özel Eğitim Okulu & 2.28828 & 1.00 \\
\hline & & Ortaokul ve Lise & -.23880 & 1.00 \\
\hline & \multirow{3}{*}{ Ortaokul } & Lise & -.01680 & 1.00 \\
\hline & & Özel Eğitim Okulu & 2.89181 & .858 \\
\hline & & Ortaokul ve Lise & .36473 & 1.00 \\
\hline & \multirow{2}{*}{ Lise } & Özel Eğitim Okulu & 2.90861 & .569 \\
\hline & & Ortaokul ve Lise & .38153 & 1.00 \\
\hline & $\begin{array}{l}\text { Özel Eğitim } \\
\text { Okulu }\end{array}$ & Ortaokul ve Lise & -2.52708 & 1.00 \\
\hline
\end{tabular}

* $\mathrm{p}<.05$

\subsection{Mesleki Doyumla ilgili Bulgular}

Öğretmenlerin mesleki doyum düzeyinin cinsiyete göre anlamlı farklılık gösterip göstermediği Mann-Whitney $U$ testi ile analiz edilmiştir. Analiz sonucunda $U=19603.0$ değeri ile $p=.000<.001$ sonucuna göre öğretmenlerin mesleki doyum düzeyinin cinsiyete göre farklıık gösterdiği ve kadın öğretmenlerin ( $\overline{\mathrm{X}}=279.74)$ mesleki doyum düzeyinin erkek öğretmenlerden ( $\overline{\mathrm{X}}=218.35)$ daha yüksek olduğu ortaya çıkmıştır.

Öğretmenlerin mesleki doyum düzeyinin yaşa göre anlamlı farklılık gösterip göstermediğini belirlemek amacıyla tek yönlü varyans analizi (One Way ANOVA) uygulanmıştır. Analiz sonucunda 22-30, 31-40, 41-50 ve 51 ve üstü yaş gruplarındaki öğretmenlerin, 3/525 serbestlik derecesinde $\mathrm{F}=5.159$ değeri ile $\mathrm{p}=.002<.01$ sonucuna göre mesleki doyum düzeyinin yaşa göre anlamlı farklılık gösterdiği ortaya çıkmıştır. Yapılan Post Hoc testine göre 22-30 yaş aralığındaki öğretmenlerin mesleki doyum düzeyinin 31-40 ve 41-50 yaş aralıklarındaki öğretmenlerden daha yüksek olduğu belirlenmiştir (Tablo 3).

Tablo 3. Öğretmenlerin mesleki doyum ölçeği puanlarının yaş değişkenine göre Post Hoc testi sonuçları

\begin{tabular}{|c|c|c|c|c|}
\hline & (I) & (J) & $\begin{array}{c}\text { Ortalamalar Arası Fark } \\
(\mathrm{I}-\mathrm{J})\end{array}$ & $\mathrm{p}$ \\
\hline \multirow{6}{*}{ MDÖ } & \multirow{3}{*}{ 22-30 yaş } & 31- 40 yaş & 3.59566 & $.005^{* *}$ \\
\hline & & 41-50 yaş & 4.10527 & $.004 * *$ \\
\hline & & 51 yaş ve üzeri & 3.38072 & .700 \\
\hline & \multirow{2}{*}{$31-40$ yaş } & 41-50 yaş & .50960 & 1.00 \\
\hline & & 51 yaş ve üzeri & -.21494 & 1.00 \\
\hline & $41-50$ yaş & 51 yaş ve üzeri & -.72455 & 1.00 \\
\hline
\end{tabular}


Öğretmenlerin mesleki doyum düzeyinin kıdeme göre anlamlı farklılık gösterip göstermediği Kruskal-Wallis testi ile analiz edilmiştir. Analiz sonucunda 5 yıl ve altı, 6-15 yıl, $16-25$ yıl ve 26 yıl ve üstü kıdem gruplarındaki öğretmenlerin, 3 serbestlik derecesinde $X^{2}=3.972$ değeri ile $p=.264>.01$ sonucuna göre mesleki doyum düzeyinin kıdeme göre anlamlı farklılık göstermediği ortaya çıkmıştır.

Öğretmenlerin mesleki doyum düzeyinin görev yapılan kurum değişkenine göre anlamlı farklılık gösterip göstermediği Kruskal-Wallis testi ile analiz edilmiştir. Analiz sonucunda okul öncesi, ilkokul, ortaokul, lise, özel eğitim okulu, ortaokul ve lise kurumlarındaki öğretmenlerin, 5 serbestlik derecesinde $X^{2}=37.659$ değeri ile $p=.000<.001$ sonucuna göre mesleki doyum düzeyinin görev yapılan kuruma göre anlamlı farklııı gösterdiği ortaya çıkmıştır. Yapılan Post Hoc testine göre okul öncesi kurumlarda çalışan öğretmenlerin mesleki doyum düzeyinin ilkokul, ortaokul, lise, ortaokul ve lise kurumlarında çalışan öğretmenlerden daha yüksek olduğu belirlenmiştir (Tablo 4).

Tablo 4. Öğretmenlerin mesleki doyum ölçeği puanlarının görev yapılan kurum değişkenine göre Post Hoc testi sonuçları

\begin{tabular}{|c|c|c|c|c|}
\hline & (I) & (J) & $\begin{array}{c}\text { Ortalamalar Arası Fark } \\
(\mathrm{I}-\mathrm{J})\end{array}$ & $\mathrm{p}$ \\
\hline \multirow{15}{*}{ MDÖ } & \multirow{5}{*}{ Okul Öncesi } & illkokul & 6.18417 & $.000 * \star \star$ \\
\hline & & Ortaokul & 7.56233 & $.000 * * *$ \\
\hline & & Lise & 7.45122 & $.000 * * *$ \\
\hline & & ÖzelEğitim Okulu & 9.81964 & .081 \\
\hline & & Ortaokul ve Lise & 6.05992 & $.002 * \star$ \\
\hline & \multirow{4}{*}{ İlkokul } & Ortaokul & 1.37816 & .999 \\
\hline & & Lise & 1.26705 & .993 \\
\hline & & Özel Eğitim Okulu & 3.63547 & .978 \\
\hline & & Ortaokul ve Lise & -.12426 & 1.00 \\
\hline & \multirow{3}{*}{ Ortaokul } & Lise & -.11111 & 1.00 \\
\hline & & Özel Eğitim Okulu & 2.25731 & 1.00 \\
\hline & & Ortaokul ve Lise & -1.50242 & 1.00 \\
\hline & \multirow{2}{*}{ Lise } & Özel Eğitim Okulu & 2.36842 & 1.00 \\
\hline & & Ortaokul ve Lise & -1.39130 & .999 \\
\hline & Özel Eğitim Okulu & Ortaokul ve Lise & -3.75973 & .981 \\
\hline
\end{tabular}

Tablo 5. Öğretmenlerin mesleki doyum ölçeği puanlarının takdir alıp almama durumuna göre Post Hoc testi sonuçları

\begin{tabular}{|c|c|c|c|c|}
\hline & (I) & (J) & $\begin{array}{c}\text { Ortalamalar Arası Fark } \\
(I-J)\end{array}$ & $\mathrm{p}$ \\
\hline \multirow{6}{*}{ MDÖ } & \multirow{3}{*}{ Her zaman } & Çoğu zaman & 3.12993 & .123 \\
\hline & & Bazı zamanlarda & 8.31579 & $.000 * * *$ \\
\hline & & Hiçbir zaman & 13.08867 & $.000 * * *$ \\
\hline & \multirow{2}{*}{ Çoğu zaman } & Bazı zamanlarda & 5.18586 & $.000 * * *$ \\
\hline & & Hiçbir zaman & 9.95874 & $.000 * * *$ \\
\hline & Bazı zamanlarda & Hiçbir zaman & 4.77288 & .178 \\
\hline
\end{tabular}


Öğretmenlerin mesleki doyum düzeyinin takdir alıp almama durumuna göre anlamlı farklılık gösterip göstermediği Kruskal-Wallis testi ile analiz edilmiştir. Analiz sonucunda her zaman, çoğu zaman, bazı zamanlarda takdir aldığını belirten ve hiçbir zaman takdir almadığını belirten öğretmenlerin, 3 serbestlik derecesinde $X^{2}=63.935$ değeri ile $p=.000<.001$ sonucuna göre mesleki doyum düzeyinin takdir alıp almama durumuna göre anlamlı farklıık gösterdiği ortaya çıkmıştır. Yapılan Post Hoc testine göre her zaman ve çoğu zaman takdir alan öğretmenlerin mesleki doyum düzeyinin bazı zamanlarda takdir alan öğretmenlerden ve hiçbir zaman takdir almayan öğretmenlerden daha yüksek olduğu ortaya çıkmıştır (Tablo 5).

Öğretmenlerin mesleki doyum düzeyinin mesleğini severek yapıp yapmama durumuna göre anlamlı farklılık gösterip göstermediği ilişkisiz örneklermler için t-testi (Independent Samples t-test) ile analiz edilmiştir. Analiz sonucunda 527 serbestlik derecesinde $t=8.328$ değeri ile $p=.000<.001$ sonucuna göre anlamlı farklılık ortaya çıkmış ve mesleğini severek yapan öğretmenlerin, mesleki doyum düzyelerinin mesleğini severek yapmayan öğretmenlerden daha yüksek olduğu belirlenmiştir.

\subsection{Bilişsel Esneklik ve Mesleki Doyum Arasındaki ilişsiye iliş̧kin Bulgular}

Öğretmenlerin genel bilişsel esneklik düzeyi ile mesleki doyum düzeyi arasında, BEE kontrol alt boyutu düzeyi ile mesleki doyum düzeyi arasında ve BEE alternatifler alt boyutu düzeyi ile mesleki doyum düzeyi arasında doğrusal ilişki olduğu belirlenmiş ve ilişkinin düzeyini belirlemek amacı ile Pearson Momentler Çarpımı Korelasyon Analizi uygulanmıştır. Analiz sonucunda öğretmenlerin bilişsel esnekliğin kontrol alt boyutu düzeyi ile mesleki doyum düzeyi arasında $r=.213$ değeri ve $p=.000<.001$ sonucuna göre düşük düzeyde, pozitif yönlü anlamı ilişki belirlenmiştir. Öğretmenlerin bilişsel esnekliğin alternatifler alt boyutu düzeyi ile mesleki doyum düzeyi arasında $r=.327$ değeri ve $\mathrm{p}=.000<.001$ sonucuna göre orta düzeyde, pozitif yönlü anlamı ilişki belirlenmiştir. Öğretmenlerin genel bilişsel esneklik düzeyi ile mesleki doyum düzeyi arasında $r=.332$ değeri ve $p=.000<.001$ sonucuna göre orta düzeyde, pozitif yönlü anlamlı ilişki belirlenmiştir (Tablo 6).

Tablo 6. Öğretmenlerin bilişsel esneklik düzeyi ile mesleki doyum düzeyine ilişkin pearson momentler çarpımı korelasyon analizi sonuçları

\begin{tabular}{lllll}
\hline & & BEE Kontrol & BEE Alternatif & BEE Genel \\
\hline Mesleki & $\mathrm{r}$ & .213 & .327 & .332 \\
Doyum & $\mathrm{p}$ & $.000^{* * *}$ & $.000^{* * *}$ & $.000^{* * *}$ \\
& $\mathrm{n}$ & 529 & 529 & 529 \\
\hline
\end{tabular}

$\star \star \star$ Korelasyon .001 düzeyinde anlamlıdır.

\section{SONUÇ, TARTIŞMA ve ÖNERILER}

Bu araştırmada öğretmenlerin bilişsel esneklik düzeyinin cinsiyet, yaş, kıdem ve görev yapılan kurum değişkenlerine göre farklılık gösterip göstermediği, mesleki doyum düzeyinin cinsiyet, yaş, kıdem, görev yapılan kurum, takdir alıp almama, mesleğini severek yapıp yapmama değişkenlerine göre farklılık gösterip göstermediği incelenmiştir. Ayrıca çalışmada öğretmenlerin bilişsel esneklik düzeyi ile mesleki doyum düzeyi arasında anlamlı bir ilişki olup olmadığı incelenmiştir.

\subsection{Sonuçlar}

Araştırma sonucunda öğretmenlerin yaşlarına, kıdem yıllarına ve çalıştıkları kuruma göre bilişsel esneklik düzeyinde anlamlı farklılıklar ortaya çıkmıştır. Öğretmenlerin bilişsel esneklik düzeyinin cinsiyetlerine göre anlamlı farkııık göstermediği belirlenmiştir. Çalışmamızda yaş değişkenine göre öğretmenlerin bilişsel esneklik düzeyine bakıldığıda, 51 ve üzeri yaştaki öğretmenlerin bilişsel esnekliğin kontrol alt boyutu düzeyinin 22-30, 31-40 ve 41-50 yaş aralıklarındaki öğretmenlerden daha yüksek olduğu görülmüştür. Bilişsel esnekliğin alternatifler alt boyutu ve genel bilişsel esneklik düzeyinde ise yaşa göre anlamlı farklılı̆a rastlanmamıştır. Örneklemi oluşturan öğretmenlerin bilişsel esnekliğin alternatifler alt boyutu düzeyi 16-25 yıl kıdeme sahip 
öğretmenlerle 5 yıl ve altı kıdeme sahip öğretmenler arasında ve 16-25 yıl kıdeme sahip öğretmenlerle 6-15 yıl kıdeme sahip öğretmenler arasında, 16-25 yıl kıdeme sahip öğretmenlerin lehine olacak şekilde anlamlı farklıık göstermektedir. Örneklemi oluşturan öğretmenlerin genel bilişsel esneklik düzeyi 16-25 yıl kıdeme sahip öğretmenlerle 5 yıl ve altı kıdeme sahip öğretmenler arasında 16-25 yıl kıdeme sahip öğretmenlerin lehine olacak şekilde anlamlı farklıık göstermektedir. Örneklemi oluşturan öğretmenlerin bilişsel esnekliğin kontrol alt boyutu düzeyi kıdemlerine göre anlamlı farklılık göstermemektedir. Bilişsel esnekliğin alternatifler alt boyutu düzeyi okul öncesi kurumda çalışan öğretmenlerle özel eğitim kurumunda çalışan öğretmenler arasında, okul öncesi kurumda çalışan öğretmenlerin lehine olacak şekilde anlamlı farklılık göstermektedir. Örneklemi oluşturan öğretmenlerin bilişsel esnekliğin kontrol alt boyutu ve genel bilişsel esneklik düzeyi görev yapılan kuruma göre anlamlı farklılık göstermemektedir.

Öğretmenlerin mesleki doyum düzeyi ile ilgili sonuçlara baktığımızda, kadın öğretmenlerin mesleki doyum düzeyinin erkek öğretmenlerden yüksek olduğu ortaya çıkmıştır. Yaş değişkenine gore bakıldığında, 22-30 yaş aralığındaki öğretmenlerin mesleki doyum düzeyinin 31-40 ve 41-50 yaş aralıklarındaki öğretmenlerden daha yüksek olduğu belirlenmiştir. Çalışmamızda öğretmenlerin mesleki doyum düzeyi kıdemlerine göre anlamlı farklılık göstermezken, okul öncesi kurumda çalışan öğretmenlerin mesleki doyum düzeyinin, ilkokulda, ortaokulda, lisede ve ortaokul ve lisede çalışan öğretmenlerden daha yüksek olduğu tespit edilmiştir. Çalışmamızda çoğu zaman ve her zaman takdir aldığını belirten öğretmenlerin mesleki doyum düzeyinin bazı zamanlarda takdir aldığını ya da hiç takdir almadığını belirten öğretmenlerden daha yüksek olduğu belirlenmiştir. Ayrıca mesleğini severek yapan öğretmenlerin mesleki doyum düzeyinin daha yüksek olduğu ortaya çıkmıştır.

Öğremenlerin bilişsel esneklik düzeyi ve mesleki doyun düzeyi arasında anlamlı ilişki olduğu gözlenmiştir. Öğretmenlerin bilişsel esnekliğin kontrol alt boyutu düzeyi ile mesleki doyum düzeyi arasında düşük, bilişsel esnekliğin alternatifler alt boyutu düzeyi ile mesleki doyum düzeyi arasında ve genel bilişsel esnekliğin düzeyi ile mesleki doyum düzeyi arasında orta düzeyde, pozitif yönlü anlamlı bir ilişki saptanmıştır.

\subsection{Tartışma}

Alanyazında bilişsel esneklik düzeyinin cinsiyete göre farklılık göstermediğini ortaya koyan ve çalışmamızın sonucunu destekleyen çeşitli çalışmalar yer almaktadır (Çuhadaroğlu, 2011; Warschburger ve ark., 2014; Yücel, 2011; Plukaard ve arkadaşları, 2015). Altunkol (2011) ise üniversite öğrencileri ile gerçekleştirdiği çalışmasında öğrencilerin bilişsel esneklik düzeyinin cinsiyetlerine göre anlamlı farklılık gösterdiğini ve erkek öğrencilerin bilişsel esneklik düzeyinin, kız öğrencilerden daha yüksek olduğunu ortaya koymuştur. Çalışmamızın örneklemini aynı meslek grubundan bireylerin oluşturmasının, bilişsel esneklik düzeyinin cinsiyete göre farklıık göstermemesinde etkili olduğu düşünülmektedir.

Zahal (2014) \%94.7'sini 17-25 yaş üniversite öğrencilerinin oluşturduğu örneklemi ile yaptığı çalışmasında bilişsel esnekliğin yaşa göre anlamlı farklılık göstermediği sonucuna ulaşmıştır. Aynı şekilde Öz (2012) örneklemini 11-24 yaş bireylerin oluşturduğu çalışmasında bilişsel esnekliğin yaşa göre anlamlı farklııık göstermediğini ortaya koymuştur. Bizim çalışmamızda öğretmenlerin bilişsel esneklik düzeyinin yaşa göre farklılık göstermesinde, örneklem grubunu oluşturan öğretmenlerin yaş aralığının geniş tutulmasının etkisi olduğu söylenebilir. 51 ve üstü yaş grubundaki öğretmenlerin bilişsel esnekliğin kontrol alt boyutu düzeyinin daha yüksek olmasında, yıllar içinde farklı olay ve problemlerle karşılaşmanın, bireylerde zor durumları kontrol edebilme algısını geliştirmesinin etkisi olabileceği düşünülmektedir.

16-25 yıl kıdeme sahip öğretmenlerin genel bilişsel esneklik düzeyinin ve bilişsel esnekliğin alternatifler alt boyutunun, daha az kıdeme sahip öğretmenlerden yüksek olduğu belirlenmiştir. Bu doğrultuda mesleklerinde tecrübe edindikçe öğretmenlerin daha bilişsel esnek olabildiği, olaylara karşı farklı bakış açıları kazandığı ve poblemlere alternative çözümler üretebildiği söylenebilir. Benzer şekilde Lee, Teo ve Chai (2010) okul öncesi öğretmenlerinin düşüncelerinde farkındalık ve 
düşüncelerini düzenleme profillerini belirlemeye çalıştıkları araştırmaları sonucunda kıdemlerine göre öğretmenlerin düşüncelerinde farkındalık ve düşüncelerini düzenleme becerileri arasında pozitif yönde anlamlı bir ilişki olduğunu tespit etmiştir.

Aberšek, Dolenc ve Kovacic (2015) ilkokul öğretmenliği ve matematik ve doğa bilimleri öğretmenliği bölümlerinde okuyan öğrencilerin anlama, problem çözme davranışlarında üstbilişsel becerileri kullanma düzeyini incelemişler ve ilkokul öğretmenliği öğrencilerin üstbilişsel becerileri kullanma düzeyinin matematik ve doğa bilimleri öğretmenliği öğrencilerinden daha yüksek olduğunu belirlemiştir. Çalışmamızda ise bilişsel esnekliğin alternatifler alt boyutu düzeyi okul öncesi kurumda çalışan öğretmenlerle özel eğitim kurumunda çalışan öğretmenler arasında, okul öncesi kurumda çalışan öğretmenlerin lehine olacak şekilde anlamlı farklılık göstermiştir. Özel eğitim kurumlarında eğitim gören öğrencilerin çeşitli alanlarda yetersizlikler yaşaması, öğretmenlerin bu alanları geliştirmek/telafi etmek adına çalışmalarını yoğunlaştırdıkları sonucunu doğurmaktadır. Okul öncesi öğretmenlerinin ise normal gelişim gösteren ve erken çocukluk döneminde olan öğrencilerle çalışmaları, öğrencilerinin gelişim alanlarını eşgüdüm içerisinde desteklemek adına, çok yönlü çalışmaları bilişsel esneklik gelişimini olumlu yönde etkilemiş olabileceğini düşündürmektedir.

Çalışmamızla benzer sonuçlara ulaşan ve kadın öğretmenlerin mesleki doyum düzeyinin erkek öğretmenlerden yüksek olduğunun belirtildiği çalışmaların (Bozkurt, 2014; Yiğit, 2007; Öcal, 2011 ve MacMillan,1999) yanı sıra, cinsiyete göre öğretmenlerin mesleki doyum düzeyinin farklılık göstermediğini (Bota, 2013 ve Vamık, 2003) ya da erkek öğretmenlerin mesleki doyum düzeyinin kadın öğretmenlerden yüksek olduğunu (Mertler, 2002) ortaya koyan çalışmalar da vardır. Çalışmamızda kadın öğretmenlerin mesleki doyum düzeyinin daha yüksek olmasında annelik duygusunun etkili olabileceği ve öğrencilerdeki gelişimeleri görmesinin, kadın öğretmenlerin mesleklerinden sağladığı doyumu olumlu yönde etkileyebileceği söylenebilir.

Çalışmamızda 20'li yaşlardaki öğretmenlerin mesleki doyum düzeyinin daha yüksek olduğu belirlenmiştir, Özcan (2013) ve Akkurt (2008) çalışmamızın sonucunu destekler şekilde, 20'li yaşlardaki öğretmenlerin mesleki doyum düzeyinin daha yüksek olduğunu belirlemiştir. Bizim çalışmamızın KKTC'de gerçekleştirilmesi ve KKTC'de genç yaştaki bireylerin iş hayatına atıldıktan sonra da ailelerinden maddi ve manevi destek görmeye devam etmesinin genç yaştaki öğretmenlerde mesleki doyum düzeyinin daha yüksek olarak belirlenmesinde etkili olabileceği öngörülmektedir. Schumacher ve arkadaşları (1995) ve Çelik (2011) çalışmalarında farklı bir sonuca ulaşmış ve öğretmenlerin yaşları ile mesleki doyum düzeyi arasında pozitif yönlü anlamlı ilişki belirlemiştir.

Çalışmamız sonucunda kıdem değişkenine göre öğretmenlerin mesleki doyum düzeylerinde anlamlı farklııık olmadığı saptanmıştır. Karabulut (2014), İzmir ilinde görev yapan ilkokul ve ortaokul öğretmenlerinin iş doyum düzeylerini incelediği çalışmasında, öğretmenlerin kıdemlerine göre iş doyum düzeylerinde anlamlı farklılık olmadığını saptamıştır. Can (2006), Türkiye'de sınıf öğretmenlerinin yaş, cinsiyet ve mesleki kıdemlerine göre iş doyum düzeylerinin belirlenmesini amaçladığı araştırmasında mesleki kıdeme göre öğretmenlerin iş doyum düzeylerinde anlamlı bir farklılı̆a ulaşılmamıştır. Karabulut ve Can'ın araştırma sonuçları çalışmamızın sonuçları ile paralellik göstermekte ve kıdem değişkenine göre öğretmenlerin mesleki doyum düzeylerinin farklılaşmadığını ortaya koymaktadır. Mesleklerinde yeni olan öğretmenlerin yıpranma payının az olması meslekten doyum almayı olumlu etkilerken, mesleklerine yıllarını vermiş öğretmenlerin de kendilerini daha yetkin hissetmesinin meslekten doyum sağlamayı olumlu etkilediği söylenebilir.

Çalışmamızda, okul öncesi kurumda çalışan öğretmenlerin mesleki doyum düzeyinin daha yüksek olduğu ortaya çıkmırtır. Çalışmamızın sonucuna paralel olarak, Landers ve arkadaşları (2008), okul öncesinden 12. sınıfa kadar farklı sınıflarda öğretim yapan öğretmenlerle yaptıkları çalışmaları sonucunda, öğretim yapılan sınıflar büyüdükçe öğretmenlerin mesleki doyumlarının azaldığını saptamıştır. Okul öncesi öğrencilerinin erken çocukluk döneminde olması, kazandırılmak istenen davranışları kolayca kazanması ve farklı durumlara uyum sağlayabilmesi açısından avantajlı bir 
dönem olabilmesinin, okul öncesi kurumda çalışan öğretmenlerin mesleki doyumlarını olumlu etkileyebileceği düşünülmektedir.

Ayrıca, çalışmamızda daha fazla takdir alan ve mesleğini severek yapan öğretmenlerin mesleki doyum düzeyinin daha yüksek olduğu belirlenmiştir. Şahin ve Dursun (2009), Biçer (2013), Ward ve Sloane (2000), Khalid ve arkadaşları (2011) yaptıkları çalışmalarda çalışmamızın sonucunu destekleyen sonuçlara ulaşırken Akkan (2008), çalışmasında, öğretmenlerin terfi imkanı ve takdir edilme konusunda yüksek tatminsizlik duyduklarını mesleki doyum düzeyini vicdani bir sorumluluk taşıma, kişileri yönlendirme, başkaları için bir şeyler yapabilme gibi iç kaynaklı faktörler sayesinde yükselttiklerini tespit etmiştir. Tok ve Bacak (2013), çalışmalarında, işlerinde en fazla doyum hisseden grubun 41 ve üzeri yaş grubunda olan öğretmenlerin olduğunu ve bu öğretmenlerin, diğer yaş gruplarına oranla işlerini daha çok sevdiklerini, işlerinde memnun geçirdikleri zamanın daha uzun süreli olduğunu belirlemiştir.

Çalışmamızda öğretmenlerin bilişsel esnekliğin kontrol alt boyutu düzeyi ile mesleki doyum düzeyi arasında düşük, bilişsel esnekliğin alternatifler alt boyutu düzeyi ile mesleki doyum düzeyi arasında ve genel bilişsel esneklik düzeyi ile mesleki doyum düzeyi arasında orta düzeyde, pozitif yönlü anlamlı bir ilişki saptanmış olması, öğretmenlerin mesleki doyum düzeyini yükseltmek konusunda bilişsel esneklik kazanmanının olumlu etkisi olabileceğini düşündürmektedir. Olaylara farklı açılardan bakabilmenin ve problemlere alternatif çözümler üretebilmenin meslekten alınan doyumu olumlu şekilde etkileyebileceği söylenebilir.

Bu çalışmanın bazı sınırlılıkları bulunmaktadır. Araştırmanın 2014-2015 öğretim yılında KKTC'de özel ve resmi okullarda görev yapan ve çalışmaya katılmaya gönüllü olan öğretmenlerle gerçekleştirilmesi ve bulguların Mesleki Doyum Ölçeği, Bilişsel Esneklik Envanteri ve araştırmacı tarafından hazırlanan Kişisel Bilgi Formu ile toplanan verilerden elde edilmesi çalışmanın sınırıııklarını oluşturmaktadır.

\section{3 Öneriler}

Sonuçlar çerçevesinde, öğretmenlik programlarında bilişsel esneklik becerilerinin gelişimini destekleyecek uygulamalara yer verilebilir. Öğretmenlerin bilişsel esneklik düzeyinin yükseltilmesinin, kendilerine sağlayacağı avantajlar konusunda bilgilendirilmesi, hem kendi bilişsel esneklik düzeyini yükseltmek hem de öğrencilerinin bilişsel olarak esnek olmaları adına çalışmalar yapmak konusunda olumlu etki yapacaktır. Öretmenlerin, meslek hayatlarında öğretim süreçlerini kendi bilişsel esnekliklerinden yararlanarak nasıl hazırlayabileceklerine yönelik çalışmalar yapılabilir. Öğretmenlerde bilişsel esnekliğin desteklenmesine, öğretmenlerin kendi uzmanlık alanları dışında farkı konularda bilgi edinebileceği, karşılaşılabilecek sorunlar ve çeşitli çözüm süreçlerinin tartışılabileceği, çeşitli uzmanlık alanlarından öğretmelerin bilgi paylaşımı yapabileceği hizmet içi eğitimlerin ve/veya çalıştayların düzenlenerek öğretmen katılımlarının teşvik edilmesi önerilebilir. Öğretmenlerin beklentileri ve doyum kaynakları arasında ortak noktalarda buluşmak adına seminerler, öğrenci ve öğretmenlerin birbirlerini anlayabilecekleri tartışma ortamları oluşturulabilir. Öğretmenlerin birbirleriyle beklenti ve becerilerini paylaşabilecekleri sağlıklı bir örgüt iklimi oluşturulabilir. Öğretmenlerin bilgi ve becerileri doğrultusunda kendilerini gösterebilecekleri imkanlar ve sorumluluklar verilerek mesleki doyum düzeyinin yükseltilmesine katı sağlanabilir. Öğretmenlerin, çalışmalarının denetlenmesi ve başarılarının adil bir şekilde ödüllendirilmesi motivasyonlarını ve mesleklerinden sağladıkları doyumu artırmada olumlu etki yapacaktır. Ileride, öğretmenlerin bilişsel esneklik düzeyini yükseltmeye yönelik programlar uygulanarak, öğretmenlerin bilişsel esneklik düzeyinin yükselmesinin mesleki doyum düzeyi üzerindeki etkisini ortaya çıkarmaya yönelik çalışmalara yer verilebilir. Bilişsel esneklik düzeyi yüksek olan öğretmenlerle, bilişsel esneklik düzeyi düşük olan öğretmenlerin öğretim süreçlerindeki farklılıklar ve öğrencileri arasında bilişsel esnekliğe dair farklılıkları ortaya koymaya yönelik çalışmalar yapılabilir. 


\section{References}

Aberšek, M. K., Dolenc, K. ve Kovacic, D. (2015). Elementary and natural science teachers' online reading metacognition. Journal of Baltic Science Education, 14(1), 121-131.

Akkan, Ö. (2008). Milli eğitime bağlı meslek okullarında görev yapan öğretmenlerin iş tatmini. Yayımlanmamış Yüksek Lisans Tezi, Yeditepe Üniversitesi, İstanbul.

Akkurt, Z. (2008). Okul öncesi öğretmenlerin iş doyumu ve tükenmişlik düzeylerinin incelenmesi. Yayımlanmamış Yüksek Lisans Tezi, Selçuk Üniversitesi, Konya.

Altunkol, F. (2011). Üniversite öğrencilerinin bilişsel esneklikleri ile algılanan stres düzeyleri arasındaki ilişkinin incelenmesi. Yayımlanmamış Yüksek Lisans Tezi, Çukurova Üniversitesi, Adana.

Aydın, A. (2000). Gelişim ve öğrenme psikolojisi (2. Baskı). İstanbul: Alfa Yayınları.

Biçer, M., (2013). ilköğretim okullarında görev yapan öğretmenlerin mesleki doyumları ile kişilik tipleri arasındaki ilişkinin incelenmesi. Yayımlanmamış Yüksek Lisans Tezi, Dokuz Eylül Üniveristesi, İzmir.

Bota, O. A. (2013). Job satisfaction of teachers. Procedia- Social and Behavioral Science, 83, 634-638.

Bozkurt, Ö. (2014). Illköğretimde beden eğitimi derslerini yürüten beden eğitimi ve spor öğretmenlerinin iş doyumu ve tükenmişlik düzeylerinin incelenmesi (Lefkoşa örneği). Yayımlanmamış Yüksek Lisans Tezi, Yakın Doğu Üniversitesi, Lefkoşa.

Çelik, O. T. (2011). Ilköğretim okulu yöneticilerinin ve öğretmenlerinin örgütsel adalet algıları ile iş doyumları arasındaki ilişki. Yayımlanmamış Yüksek Lisans Tezi, Selçuk Üniversitesi, Konya.

Çuhadaroğlu, A. (2011). Bilişsel esnekliğin yordayıcıları. Yayımlanmamış Doktora Tezi, AnkaraÜniversitesi, Ankara.

Eren, E. (2010). Örgütsel davranış ve yönetim psikolojisi (12. Baskı). İstanbul: Beta Yayıncılık.

Güler, A. S. (2009). Tourette sendromu olan çocuk ve ergenlerde bilişsel esneklik ve sosyal karşılıklıık. Uzmanlık Tezi, Marmara Üniversitesi, İstanbul.

Gülüm, í. V. ve Dağ, í. (2012). Tekrarlayıcı düşünme ölçeği ve bilişsel esneklik envanterinin türkçeye uyarlanması, geçerliliği ve güvenilirliği. Anadolu Psikiyatri Dergisi, 13, 216-223.

Gülüm, í. V. ve Dağ, İ. (2013). Yetişkin bağlanma örüntüleri ile psikopatoloji belirtileri arasındaki iliş̧kide bilişsel özelliklerin aracı rolü: Bilişsel esneklik. Türk Psikiyatri Dergisi, 24(4), 240-247.

Gülüm, V. (2014) Bilişsel Esneklik Envanteri - BEE, volkangIm@gmail.com, Bahar Üzümcü'ye kişisel e-posta, bahar_zmc@hotmail.com.

Hongying, S. (2007). Literature review of teacher job satisfaction. Chinese Education and Society, 40(5), 11-16.

Kan, Ü. D. (2008). Bir grup okul öncesi öğretmeninde tükenmişlik durumunun incelenmesi. Kastamonu Eğitim Dergisi, 16(2), 431- 438.

Karakuzu, S. (2013). Denizli il merkezlerinde bulunan ilkokullarda görev yapan sınf öğretmenleri ve ortaokullarda görev yapan branş öğretmenlerinin iş doyumunun incelenmesi. Yayımlanmamış Doktora Tezi, Gazi Üniversitesi, Ankara.

Khalid, S., Irshad, M. Z. ve Mahmood, B. (2012). Job satisfaction among academic staff: a comparative analysis between public and private sector universities of punjab, Pakistan. International Journal of Business and Management, 7(1), 126-136.

Kılıç, F. ve Demir, Ö. (2012). Sınıf öğretmenliği öğrencilerinin bilişsel koçluk ve bilişsel esnekliğe dayalı öğretim ortamlarının oluşturulmasına ilişkin görüşleri. Illköğretim Online, 11(3), 578-595.

Koçakoğlu, M. (2010). Probleme dayalı öğrenme: Yapılandırmacılığın özü. Milli Eğitim National Education, 39(118), 68-82.

Kuzgun, Y. ve Bacanlı, F. (2011). Rehberlik ve psikolojik danışmada kullanılan ölçekler. Ankara: Nobel Yayın Dağııım. 
Kuzgun, Y., Sevim, S. A. ve Hamamcı Z. (1999). Mesleki doyum ölçeğinin geliştirilmesi. Türk Psikolojik Danışma ve Rehberlik Dergisi, 2(11), 14-18.

Küçükahmet, L. (1999). Öğretmenlik mesleğine giriş (2. Baskı). Bursa: Alkım Yayınları.

Landers, E., Alter, P. ve Servilio, K. (2008). Students' challenging behavior and teachers' job satisfaction. Beyond Behavior, 18(1), 26-33.

Lee, C. B., Teo, T. ve Chai, C. S. (2010). Profiling pre-service teachers' awareness and regulation of their own thinking: Evidence from an Asian country. Teacher Development: An international Journal of Teachers' Professional Development, 14(3), 295-306.

MacMillan, R.B. ve Ma, X. (1999). Influence of workplace conditions on teachers' job satisfaction. The Journal of Education Researh, 93(1), 39-47.

Martin, M. M. ve Anderson, C. M. (1998). The cognitive flexibility scale: Three validity studies. Communication Reports, 11(1), 1-9.

Mertler, C. A. (2002). Job satisfaction and perception of motivation among middle and high school teachers. American Secondary Education, 31(1), 43-53.

Öcal, Ö. (2011). Ilköğretim okullarında görev yapan öğretmenlerin iş tatmini düzeylerinin demografik özelliklere göre incelenmesi. Yayımlanmamış Yüksek Lisans Tezi, Maltepe Üniversitesi, İstanbul.

Öz, S. (2012). Ergenlerin cinsiyet, sosyo-ekonomik ve öğrenim kademesi düzeylerine göre bilişsel esneklik, uyum ve kaygı puanları arasındaki ilişkilerin incelenmesi. Yayımlanmamış Yüksek Lisans Tezi, Çukurova Üniversitesi, Adana.

Özben, Ş. ve Argun, Y. (2005). Sosyo demografik özelliklere göre ilköğretim öğretmenlerinin iş doyumu ve tükenmişlik düzeylerinin incelenmesi. Dokuz Eylül Üniversitesi Buca Eğitim Fakültesi Dergisi, 18, 27-37.

Özcan, Z. E. (2013). Illköğretim okullarında görev yapan öğretmenlerin iş doyumu (Niğde örneği). Yayımlanmamış Yüksek Lisans Tezi, Gazi Üniversitesi, Ankara.

Pearson, L. C. ve Moomaw, W. (2005). The relationship between teacher autonomy and stress, work satisfaction, empowerment, and professionalism. Educational Research Quarterly, 29(1), 3854.

Plukaard, S., Huizinga, M., Krabbendam, L. ve Jolles, J. (2015). Cognitive flexibility in healthy students is affected by fatigue: An experimental study. Learning and Individual Differences, 38, $18-25$.

Sancar, M. (2009). Leadership behaviors of school principals in relation to teacher job satisfaction in North Cyprus. Procedia Social and Behavioral Sciences, 1, 2855-2864.

Schumacher, P., Ilacqua, J. A. ve Li, H. C. (1995). Factors contributing to job satisfaction in higher education. Education, 116(1), 51-61.

Spiro, R. J., Feltovich, P. J., Jacobson, M. J. ve Coulson, R. L. (1988). Cognitive flexibility theory: Advanced knowledge acquisıtion in ill-structured domains. A Readıng Research and Educatıon Center Report, University of Illinois at Urbana, Champaign.

Spiro, R. J., Feltovich, P. J., Jacobson, M. J. ve Coulson, R. L. (1992). Cognitive flexibílity, constructivism, and hypertexfu random access instruction for advanced knowledge acquisition in III-structured domains. Lawrence Erlbaum Associates, Publıshers.

Stempien, L. R. ve Loeb, R. C. (2002). Differences in job satisfaction between general education and special education teachers. Remedial and Special Education, 23(5), 258-267.

Şahin, I. (2013). Öğretmenlerin iş doyum düzeyleri. YYÜ Eğitim Fakültesi Dergisi. 10(1), 142-167.

Şahin, H. ve Dursun, A. (2009). Okul öncesi öğretmenlerinin iş doyumları: Burdur örneği. Mehmet Akif Ersoy Üniversitesi Eğitim Fakültesi Dergisi. 9(18), 160-174.

Tayfunoğlu, N. S. (2006). KKTC ilkokul öğretmenlerinde iş doyumu ve tükenmişlik ilişkisi. Yayımlanmamış Yüksek Lisans Tezi, Yakın Doğu Üniversitesi, Lefkoşa. 
Tok, T. N. ve Bacak, E. (2013). Öğretmenlerin iş doyumu ile yöneticileri için algıladıkları dönüşümcü liderlik özellikleri arasındaki ilişki. International Journal of Human Science, 10(1), 1135-1166.

Treputtharat, S. ve Tayiam, S. (2014). School climate affecting job satisfaction of teachers in primary education, Khon Kaen, Thailand. Procedia-Social and Bheavioral Science, 116, 996-1000.

Tümkan, F. (2008). Devlet ve özel ilkokul öğretmenlerinin iş doyum düzeyleri ile ilgili araştırma (Lefkoşa örneği). Yayımlanmamış Yüksek Lisans Tezi, Yakın Doğu Üniversitesi, Lefkoşa.

Vamık, N. (2003). ilkokul öğretmenlerinin iş doyum düzeyleri (iskele ilçesi örneği. Yayımlanmamış Yüksek Lisans Tezi, Yakın Doğu Üniversitesi, Lefkoşa.

Vural, B. (2004). Yetkin-ideal-vizyoner öğretmen. İstanbul: Hayat Yayınları.

Ward, M. E. ve Slone, P.J. (2000). Non-pecuniary advantages versus pecuniary disadvantages; job satisfaction among male and female academics in Scottish Universities. Scottish Journal of Political Economy, 47(3), 273-303.

Warschburger, P., Pfeiffer, E., Lehmkuhl, U. ve Schneider, N. (2013). Cognitive flexibility in adolescent patients with unipolar affective disorders-gender differences. $Z$ Kinder Jugendpsychiatr Psychother, 41(4), 261-70.

Woods, A. M. ve Weasmer, J. (2002). Maintaining job satisfaction: Engaging professionals as active participants. The Clearing House, 75(4), 186-189.

Yıldız, B. (2013). Illkokul ve ortaokul öğretmenlerinin iş stresi, örgütsel bağlılık ve iş doyumuna yönelik algılarının incelenmesi. Yayımlanmamış Yüksek Lisans Tezi, Maltepe Üniversitesi, İstanbul.

Yiğit, A. (2007). Özel eğitim kurumlarında çalışan öğretmenlerin iş doyumu tükenmişlik ve ruh sağılı düzeylerinin çeşitli değiş̧kenler açıından incelenmesi. Yayımlanmamış Yüksek Lisans Tezi, Niğde Üniversitesi, Niğde.

Zahal, O. (2014). Özel yetenek sınavına giren adayların öğrenme stilleri ve bilişsel esneklij düzeyleri ile sınav başarıları arasındaki ilişki. Yayımlanmamış Doktora Tezi, İnönü Üniversitesi, Malatya. 


\section{Extended Summary}

The development of cognitive flexibility of students' skills and cognitive flexibility of structure to support information acquisition, flexible learning environments, and the same information in a variety of ways and for a variety of purposes, requires to be discoverable. According to cognitive flexibility theory of "cognitive" part, the acquisition of knowledge to be recalled learned instantly old, "flexibility" of which should be used while flexibly in various fields of knowledge gained (Spiro et al., 1992). Examination of job satisfaction of teachers in the education of the individuals and gaining them to society possess a particular importance (Kan, 2008). Cognitive flexibility is a must have and no longer will train teachers to students and new incorporation among the attributes that are required (Kılıç and Demir, 2012). Higher job satisfaction of teachers, their training and their contribution to performance can be said to be higher. Established relationships with students, teachers, colleagues and school leaders, individual ideas passing opportunities, salary and vacation opportunities, school environment and working conditions, timetables, promotion opportunities, and admired their satisfaction of teachers' occupational factors such as resources (Vural, 2004).

It is emphasized that setting up good relations with teachers, students, administrators and personal interests can have positive effect on teachers' job satisfaction. People with high levels of cognitive flexibility, interpersonal relationships, feel themselves enough enterprise, responsibility, problem solving skills, advanced, flexible and flexible to adapt to new situations in cases where they feel themselves possessed by a given competent, cognitive flexibility in the level of teachers job satisfaction levels will be affected.

Referring to the literature "cognitive flexibility" have not been dealt with issues of "job satisfaction". In the Turkish Republic of Northern Cyprus "cognitive flexibility" would be a significant move in this study was conducted of the relationship has not been seen in a study of the issues dealt with and between teachers and job satisfaction levels of cognitive flexibility. In this study, cognitive flexibility, and that teachers and what factors affect the level of job satisfaction levels and cognitive flexibility is intended to reveal the relationship between the levels of job satisfaction.

This study was a quantitative survey model. The study sample was composed by the convenience sampling method. Working in the Turkish Republic of Northern Cyprus in the 2014-2015 academic year, pre-school, elementary, middle, high school and it was carried out with 529 teachers working in 54 schools, including special schools. To determine cognitive flexibility level of the teacher Cognitive Flexibility Inventory was used that is developed by Dennis and Wal (2010) and adapted to Turkish by Gülüm and Dağ (2012). In order to determine the job satisfaction level Job Satisfaction Scale was used that is developed by Sevim and Hamamci (1999). Personal Information Form prepared by the researcher was used. The obtained data were analysed with SPSS. Independent groups of cases can be assumed equal variance t-test (independent samples t-test), and one-way analysis of variance (One Way ANOVA) and differences were identified. Variances in cases where there are significant differences between Mann-Whitney and Kruskal-Wallis test for differences were detected. The relationship between cognitive flexibility and job satisfaction level of teachers were evaluated with Pearson Product Moment Correlation Coefficient.

Results showed that there are significant differences between age in controlling subscale $(p<.05)$. It was found that there are significant difference between teachers' seniority and alternatives subscale $(p<.05)$. There are significant difference between teachers' seniority and general cognitive flexibility $(p<.05)$. It was found that there are significant difference between teachers' institution and alternatives subscale $(p<.05)$.

There are significant difference between job satisfaction and gender $(p<.001)$, age $(p<.01)$, the task performed by institution $(p<.001)$, according to the discretion and who are not $(p<.001)$ and love the job or not $(p<.001)$.

It was found that there is a positive correlation between cognitive flexibility and job satisfaction $(p<.001)$. There is significant positive correlation between control subscale of cognitive flexibility 
scale and job satisfaction $(p<.001)$. There is significant positive correlation between alternatives subscale of cognitive flexibility scale and job satisfaction $(p<.001)$.

In this study, teachers aged 51 and over are higher than the younger teachers in controlling subscale of cognitive flexibility scale. Zahal (2014) and Öz (2012) reached a different conclusion in these studies were not found to be significantly different according to age of the cognitive flexibility. The different results obtained in our study, constituting the sample group of teachers may be influenced the retention of a wide age range. 16-25 years seniority teachers with alternative subscale of cognitive flexibility scale has been found to be higher than teachers with less seniority level. Lee, Teo and Chai (2010) also demonstrated that a significant positive correlation between cognitive skills and seniority of the teachers in their work. In this regard, the experience may be playing a positive role in the development of cognitive flexibility. According to the results, depends on institutions variables, the teachers working with pre-school was found higher than working in private educational institutions to the alternative subscale of cognitive flexibility scale.

Female teachers' job satisfaction levels were higher than male teachers, the level of job satisfaction of teachers in the 22-30 age range was determined to be higher than the older teachers. Özcan (2013) and Akkurt (2008) results support our study, when determining higher job satisfaction level of teachers in the age of 20, Schumacher et al (1995) and Çelik (2011) among job satisfaction levels and ages of different conclusion was reached and teachers set a positive significant correlation.

As a conclusion cognitive flexibility and job satisfaction levels vary according to the demographic variables of teachers and teachers' level of cognitive flexibility were determined to be a positive correlation between levels of job satisfaction. Teachers and the teaching profession after the start of the training program should include efforts to raise levels of cognitive flexibility of teachers. Considering the factors affecting the level of job satisfaction of teachers, arrangements should be made in schools and the education system and teachers must be enhanced in level of job satisfaction. Also in enhancing the efficiency obtained in the teaching process with the aim of attracting more attention to improvements, which can contribute to teacher qualifications and job satisfaction levels, it is suggested that conduct studies to demonstrate the impact of education. 